\title{
GALERI ANGGREK INDONESIA DI JAKARTA
}

\author{
Rossa Yolanda ${ }^{1)}$, Diah Anggraini ${ }^{2)}$ \\ 1) Program Studi S1 Arsitektur, Fakultas Teknik, Universitas Tarumanagara, rossayolanda@gmail.com \\ ${ }^{2)}$ Program Studi S1 Arsitektur, Fakultas Teknik, Universitas Tarumanagara, diah_ismono@yahoo.com
}

\begin{abstract}
Abstrak
Jakarta sebagai ibukota negara merupakan pusat aktivitas berbagai aspek kehidupan, di dalamnya termasuk kegiatan pariwisata. Arsitektur berperan tidak hanya sebagai penyedia fasilitas pariwisata, namun menjadi dapat menjadi daya tarik pariwisata itu sendiri terutama melalui pengolahan dan kehadiran wujud fisik arsitektur. Selain wujud fisik arsitektur yang menarik, program yang diberikan harus mempunyai daya tarik bagi wisatawan. Wisata Anggrek menjadi pilihan karena dapat menjadi daya tarik bagi wisatawan lokal maupun mancanegara karena jenisnya yang beragam dan cara hidupnya yang unik. Cara hidup anggrek dijadikan ide dalam proyek ini. Anggrek dapat hidup secara epifit dan semi epifit (menempel pada tumbuhan lain), terestrial (tanah), dan saprofit (benda mati). Selain cara hidup, iklim yang sesuai untuk tanaman anggrek juga harus diperhatikan, karena anggrek mampu hidup di berbagai iklim di Indonesia. Sehingga pada proyek ini ruang untuk anggrek dibagi menjadi 4 yaitu, anggrek epifit - semi epifit - saprofit, anggrek terestrial, anggrek pada iklim dingin, dan herbarium anggrek. Aktivitas utama pada keempat ruang untuk anggrek adalah observasi. Selain aktivitas observasi, terdapat juga aktivitas interaksi, meliputi merangkai bunga dan merawat bunga, sekaligus memiliki aktivitas pendukung yaitu, berbelanja dan kuliner. Proyek ini diharapkan menjadi tujuan bagi wisatawan lokal maupun mancanegara karena mampu mewadahi beragam koleksi Anggrek Indonesia, menjadi pusat pameran anggrek di Indonesia dan menumbuhkan rasa cinta terhadap flora dan alam tempat tinggalnya.
\end{abstract}

Kata kunci: anggrek, Indonesia, Jakarta, kota metropolitan, wisata arsitektur

\begin{abstract}
Jakarta is the center of various aspect of life, including tourism. Architecture not only become the facility, but become the main attraction, especially through processing and the presence of physical form.Besides the form, activites inside also important. Orchid tourism is selected, because it can attract local and foreign people. Orchid has so many species and unique way of life. It's $f$ unique become the concept of this project. Orchid can live on other plants (epiphyte and semi epiphyte ), soil (terrestrial), and inanimate objects (saprophyte). Besides that, climate must be appropriate, because it can live in various climate in Indonesia.. In this project, it divides into 4 spaces namely, epiphyte - semi epiphyte - saprophyte, terrestrial, cold climate, and herbarium. The main activity on all four spaces is observation. In addition to observation activities, there also interactions activity, namely flower arrangement and caring for flower. Also has supporting activities shopping and culinary. This project is expected to be a destination for local and foreign tourists because it able to accomodate the diverse collection of Indonesian Orchids, become a biggest gallery for orchids in Indonesia and foster love for flora and it's habitat.
\end{abstract}

Keywords: architourism, Indonesia, Jakarta, metropolis, orchid

\section{PENDAHULUAN}

Jakarta sebagai ibukota negara Indonesia, juga merupakan kota metropolis. merupakan pusat aktivitas berbagai bidang. Penduduk di Jakarta melakukan semua aktivitasnya mulai dari bekerja, sekolah, tinggal, hingga berbelanja di tengah padatnya Jakarta. Sehingga penduduk Jakarta sangat memerlukan relaksasi, dengan cara pergi ke tempat-tempat pariwisata, di dalam maupun luar kota. Sedangkan wisatawan mancanegara datang ke Jakarta karena ingin 
mendapatkan pengalaman dan menjelajahi keunikan Indonesia. Sehingga objek pariwisata yang diusulkan adalah objek pariwisata dengan keunikan alam Indonesia yang memberikan pengalaman yang jauh dari kebisingan kota Jakarta.

Indonesia memiliki potensi alam yang mampu dijadikan objek pariwisata, yaitu anggrek. Anggrek sebagai puspa pesona Indonesia menjadi salah satu keunikan yang ada di Jakarta, yang merupakan daerah penghasil anggrek terbesar ketiga di Indonesia (2015). Indonesia sendiri memiliki 5000 jenis bunga anggrek. Namun sayangnya, anggrek yang tinggal di alam mulai terancam kelestariannya karena habitatnya yang semakin rusak. Di hutan-hutan di seluruh Indonesia tempat tinggal anggrek alam setiap tahunnya semakin berkurang.

Di Jakarta terdapat 2 objek wisata yang menggunakan anggrek sebagai daya tariknya yaitu, Taman Anggrek Ragunan dan Taman Anggrek Indonesia Permai. Namun kedua tempat di atas hanya menawarkan fasilitas untuk "melihat - lihat" dan menjual anggrek. Tidak terdapat kegiatan-kegiatan yang melibatkan wisatawan dengan anggrek secara langsung maupun usaha konservasi untuk anggrek didalamnya. Berdasarkan kondisi tersebut maka perlu objek pariwisata yang juga berperan sebagai kawasan konservasi in-situ maupun eks-situ. Konservasi eks-situ menjadi tempat rekreasi yang bersifat mendidik, dengan membuat habitat-habitat buatan untuk jenis anggrek bukan hutan tropis (anggrek epifit, anggrek terrestrial, anggrek litofit, dan anggrek semi epifit) (Purwanto, 2016).Sedangkan konservasi in-situ menjadi tempat rekreasi yang berada di alam, yang juga bersifat mendidik. Di dalamnya dapat diberikan berbagai penjelasan mengenai seluk beluk anggrek, mulai dari identitas hingga pola hidup anggrek tersebut. Selain itu wisatawan yang datang dapat mengikuti usaha konservasi anggrek. Contohnya ketika proses penanaman, pemupukan, atau penyiraman. Setiap wisatawan yang datang dan turut ikut dalam usaha konservasi anggrek ini kemudian diberikan semacam apresiasi karena turut berpartisipasi dalam konservasi anggrek. Dengan adanya apresiasi yang diberikan kepada wisatawan yang datang, diharapkan tumbuh rasa peduli terhadap kondisi flora dan habitatnya, terutama anggrek.

\section{KAJIAN LITERATUR}

\section{Pariwisata dan Arsitektur}

Pariwisata adalah kegiatan berpergian ke suatu tempat di luar lingkungannya yang biasa dalam waktu tidak lebih dari satu tahun secara terus menerus, untuk kesenangan, bisnis, atau melepas jenuh. Wisatawan nusantara adalah wisatawan yang berasal dari dalam negeri dan wisatawan mancanegara adalah warga negara suatu negara yang berwisata keluar dari negaranya (KBBI). Dengan tujuan memperoleh kesenangan, tidak untuk bekerja, menetap, dan mencari nafkah (Suwantoro, 2004).

Architourism merupakan gabungan dari kata architecture dan tourism. Kedua kata ini muncul sejak adanya The Bilbao Effect. Sebelum The Bilbao Effect, arsitektur berperan untuk mendukung keperluan wisata yang disebut arsitektur wisata. Namun setelahnya, arsitektur sendiri menjadi atraksi wisata karena singnifikansi bentuknya terhadap lingkungannya (Specht, 2014).

\section{Potensi Wisata Ekologi Anggrek}

Wisata ekologi (Ziffer, 1989) adalah bentuk pariwisata yang terinspirasi dari riwayat suatu daerah, termasuk budaya didalamnya.

Prinsip Ekowisata (DirJen Pengembangan Destinasi Pariwisata, 2009) antara lain:

a. Kegiatan ekowisata harus bersifat ramah lingkungan, secara ekonomis dapat berkelanjutan dan serasi dengan kondisi sosial dan kebudayaan Daerah Tujuan Ekowisata (DTE)

b. Untuk menjamin konservasi alam dan keanekaragaman hayati sebagai sumber daya kepariwisataan utama, segenap upaya penting harus dilaksanakan untuk menjamin fungsi dan daya dukung lingkungan agar tetap terjaga.

c. Kegiatan ekowisata yang secara langsung mendukung pada upaya perlindungan alam dan 
kelestarian keanekaragaman hayati harus dipromosikan.

d. Harus ada tindakan pencegahan untuk menghindari dan meminimalkan dampak negatif keanekaragaman hayati yang disebabkan kegiatan ekowisata.

e. Pengembangan kegiatan ekowisata hendaknya selalu menggunakan teknologi ramah lingkungan.

f. Semua yang terlibat dalam pengelolaan ekowisata termasuk pemerintah swasta atau Lembaga Swadaya Masyarakat (LSM) harus bertanggung jawab secara bersama untuk mencapai bentuk ekowisata yang berkelanjutan.

g. Konsep dan kriteria ekowisata berkelanjutan harus dikembangkan dan dikaitkan dengan program pendidikan dan pelatihan untuk pekerja dibidang kepariwisataan.

h. Masyarakat harus diberikan kemudahan untuk memperoleh informasi sebanyak-banyaknya mengenai manfaat perlindungan lingkungan dan konservasi keanekaragaman hayati melalui bentuk ekowisata yang berkelanjutan tadi.

Indonesia memiliki kekayaan flora yang banyak. Hal tersebut dikarenakan iklim dan cuaca yang sesuai untuk tempat berkembangnya flora. Menurut Bappenas, Indonesia memiliki $10 \%$ jenis tumbuhan berbungan yang terdapat diseluruh dunia. Kekayaan flora ini semakin berkembang karena didukung oleh teknologi yang ada sekarang yaitu, hortikultura. Sehingga flora bisa dikembangkan menjadi varietas yang lebih banyak dan dapat dikembangkan diluar habitat aslinya.

Anggrek yang merupakan bunga nasional kategori puspa pesona sebagai daya tarik wisata. Bunga anggrek selain merupakan bunga nasional, memiliki banyak penggemar baik lokal maupun mancanegara. Anggrek yang habitat aslinya merupakan hutan hujan tropis, mulai kehilangan tempat tinggalnya. Dari 30 jenis anggrek langka yang ada di Indonesia, 6 diantaranya berasal dari Jawa. Setiap harinya hutan-hutan habitat asli anggrek ini semakin berkurang begitu pula anggrek yang tinggal didalamnya. Sehingga pemerintah lewat Puslitbang Hortikultura melakukan banyak penelitian dalam usaha budidaya anggrek dengan tujuan mampu menghasilkan anggrek yang lebih baik dan varian yang lebih banyak.

Anggrek adalah anggota suku Orchidaceae dengan keanekaragaman tertinggi di dunia. Diperkirakan terdapat 35.000 jenis anggrek yang tersebar diseluruh dunia dan kurang lebih 5.000 jenis anggrek ditemukan di Indonesia ( $Y$ \& B, 2003). Tanaman anggrek tersebar diseluruh bagian dunia namun lebih banyak tumbuh pada daerah tropis. Tanaman anggrek tumbuh tersebar pada daratan rendah hingga tinggi, sesuai dengan varietasnya. Terdapat pula varietas anggrek yang hanya ditemukan tumbuh disuatu tempat tertentu sehingga disebut sebagai jenis anggrek endemik.

Anggrek merupakan salah satu tanaman komoditas prioritas dan unggulan menurut Puslitbang Hortikultura. Komoditas prioritas berarti komoditas yang didahulukan dan diutamakan daripada komoditas yang lain. Komoditas unggulan berarti komoditas yang lebih baik daripada yang lain atau terbaik. Jakarta memiliki lahan panen sebesar $2260 \mathrm{~m}^{2}$ (Badan Pusat Statistik tahun 2015 tentang Statistik Tanaman Hias Indonesia). Varietas Anggrek berdasarkan sifat hidupnya yaitu, Anggrek Epifit, Anggrek Semi Epifit, Anggrek Terestrial, dan Anggrek Saprofit. (Purwanto, 2016)

- Anggrek Epifit adalah jenis anggrek yang menumpang pada tanaman lain tetapi tidak merugikan yang ditumpangi. Bagian yang menempel pada tanaman lain adalah akarnya. Namun akar ini hanya berfungsi sebagai jangkar. Sehingga anggrek jenis ini bisa hidup menempel di objek bukan makhluk hidup (misalnya : tebing).

- Anggrek Semi Epifit adalah jenis anggrek yang menumpang pada tanaman lain. Bagian yang menempel pada tanaman lain adalah akarnya. Akar ini selain berfungsi sebagai jangkar, juga berfungsi mencari sumber makanan.

- Anggrek terestrial adalah jenis anggrek yang hidupnya berada diatas tanah.

- Anggrek Saprofit adalah jenis anggrek yang hidup menempel pada sampah atau humus. 
Anggrek jenis ini tidak memiliki daun. Tugas daun diambil alih oleh akarnya.

Varietas Angrek berdasarkan iklim tempat tinggalnya yaitu, anggrek panas, anggrek sedang, dan anggrek dingin.

- Anggrek panas memerlukan suhu udara $26-30 \mathrm{C}^{\circ}$ pada suang hari, $21 \mathrm{C}^{\circ}$ pada malam hari. Contoh: Dendrobium phalaenopsis, Onchidium papillo, Phaphilopedillum bellatum.

- Anggrek sedang memerlukan suhu $21 \mathrm{C}$ (Specht, 2014) pada siang hari dan 15-21 C pada malam hari.

- Anggrek dingin memerlukan suhu 15-21 $C^{\circ}$ pada siang hari dan 9-15 $C^{\circ}$ pada malam hari. Contoh: Cymbidium hartinahianum, Cymbidium borneens.

\section{METODE}

Arsitektur tidak hanya sebagai penyedia fasilitas pariwisata, namun dapat berperan menjadikan obyek atau bangunan wisata sebagai daya tarik pariwisata itu sendiri. Wujud fisik arsitektur menjadi penting sehingga menggunakan dapat menjadikan pendekatan pragmatis sebagai metode desainnya. Desain pragmatis merupakan proses desain yang melewati proses coba-coba / trial and error (Broadent, 1973). Metode lain yang dapat digunakan adalah dengan studi preseden yaitu, studi terhadap bangunan serupa.

Proyek ini melakukan analisis terhadap fungsi kawasan dan lingkungan fisik sekitar lokasi tapak dalam proses menyusun program aktivitas dan bentuk arsitektural dalam proyek ini, serta melakukan studi preseden sebagai contoh yang dilakukan berulang-ulang, sehingga dianggap paling sesuai tujuan yang ingin dicapai.

\section{DISKUSI DAN HASIL}

Lokasi

Objek pariwisata dengan anggrek sebagai daya tarik utama ada 2 di Jakarta, yaitu Taman Anggrek Ragunan (Jakarta Selatan) dan Taman Anggrek Indonesia Permai (Jakarta Timur). Taman Anggrek Ragunan memiliki zonasi hijau dengan Koefisien Dasar Bangunan (KDB) 0, tidak memungkinkan untuk dibangun bangunan. Fungsi di sekitarnya sudah sesuai zonasi sehingga tidak dipilih sebagai lokasi proyek.

Taman Anggrek Indonesia Permai memiliki zonasi perkantoran dengan KDB 30\%, sehingga memungkinkan untuk dibangun bangunan. Fungsi disekitarnya masih belum sesuai dengan zonasi, sehingga bisa dialih fungsikan untuk proyek. Tapi di sekitar lokasi ini tidak ada sumber mata air yang memadai untuk proyek, sehingga tidak dipilih sebagai lokasi proyek. Para wisatawan biasanya datang untuk berwisata tidak hanya ke satu destinasi, tapi beberapa objek wisata sekaligus. Sehingga lebih menguntungkan proyek pariwisata ini jika diletakkan pada suatu kawasan pariwisata.

Berdasarkan PP Republik Indonesia No.50 tahun 2011 tentang Rencana Induk Pembangunan Kepariwisataan Nasional, Jakarta memiliki 4 destinasi pariwisata yaitu (1) Kepulauan Seribu (indikasi program : Wisata Bahari), (2) Kota Tua - Sunda Kelapa (Wisata Budaya Peninggalan Sejarah), (3) CBD Jakarta (Wisata Belanja), dan (4) Cibubur - TMII (Wisata Khusus).

Objek Pariwisata sebaiknya memiliki akses transportasi umum yang baik. Sehingga mudah diakses oleh wisatawan lokal maupun mancanegara. Selain moda transportasi, akses berupa sarana jalan juga penting. Jalan yang dilewati harus bisa diakses umum.

Pada titik merah yang berada di Jl. Gatot Subroto, dekat dengan Kali Krukut dan Kali Mampang, kondisi eksisting masih belum sesuai dengan zonasi yang disarankan pemerintah DKI Jakarta. Sehingga bisa dipilih sebagai lokasi proyek. Titik ini berada Kecamatan Mampang Prapatan, Kelurahan Kuningan Barat (Gambar 1). 


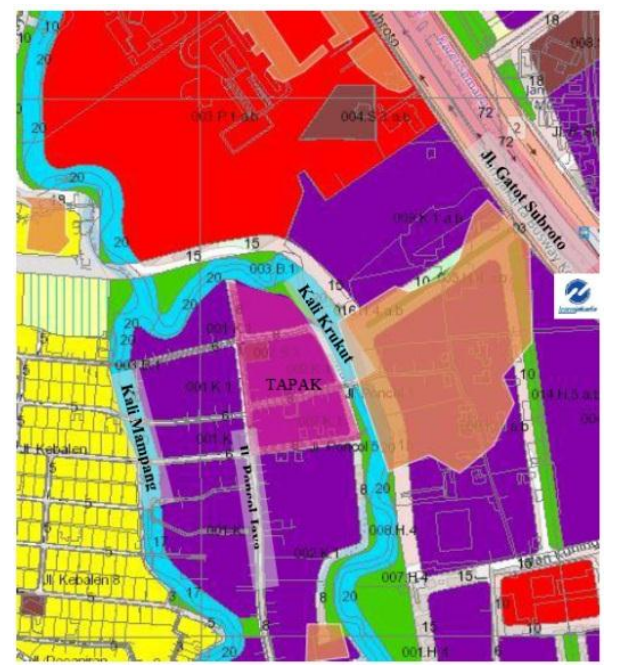

Gambar 1. Peta Zonasi Tapak

Sumber: PD Provinsi DKI Jakarta No.1 tahun 2014 tentang Rencana Detail Tata Ruang dan Peraturan Zonasi

Tapak berada disebelah timur dari Kali Mampang. Dapat diakses lewat Jl. Gatot Subroto dan Jl. Kapten Tendean. Lokasi ini termasuk kedalam Kawasan Destinasi Wisata CBD Senayan yang relatif mudah diakses dengan transportasi umum dan juga dilewati zonasi hijau dan biru. Menurut Peraturan Zonasi tapak memiliki ketentuan sebagai berikut:

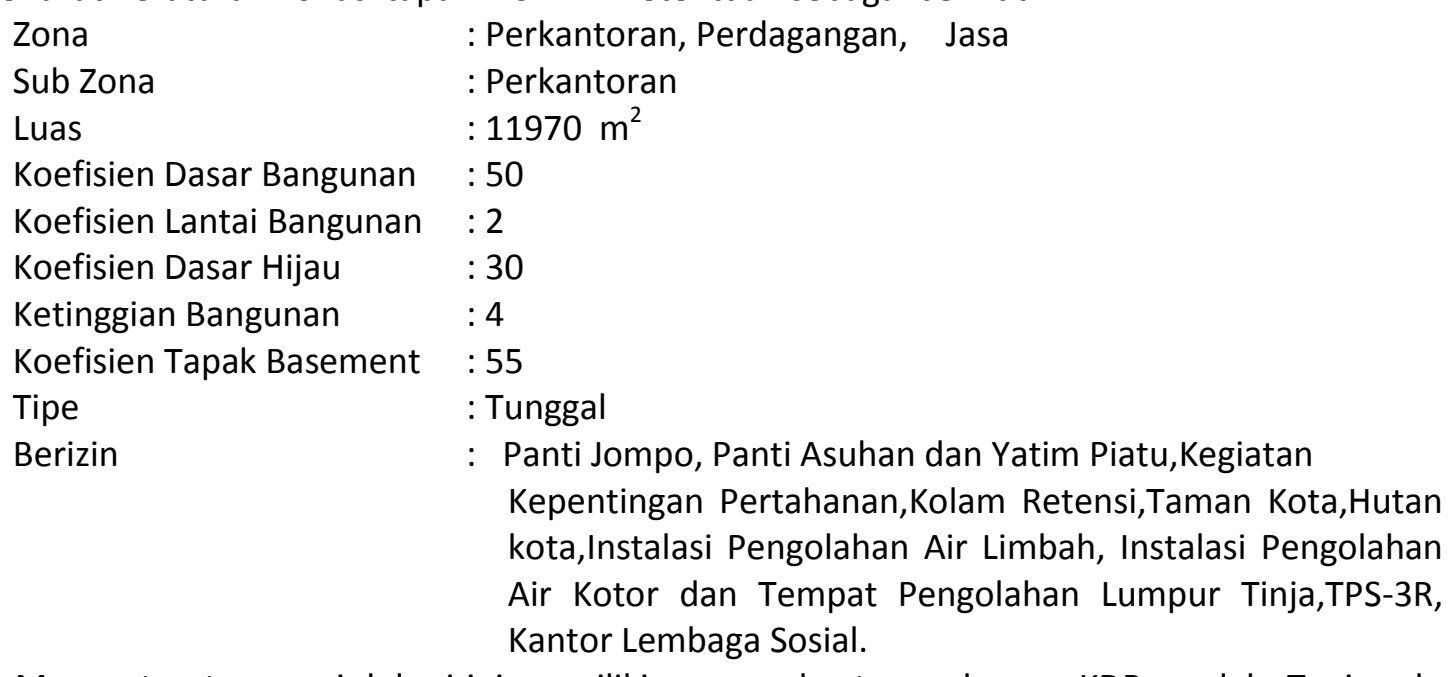

Menurut peta zonasi, lokasi ini memiliki zona perkantoran dengan KDB rendah. Tapi pada eksistingnya, lokasi ini masih merupakan perumahan. Sehingga diusulkan untuk dialih fungsinya untuk proyek.

\section{Program Aktivitas}

Aktivitas utama berupa kegiatan observasi dan interaksi. Kegiatan observasi pada taman diperuntukan untuk anggrek yang habitatnya berada di hutan tropis dan dibuat dalam bentuk outdoor dan semi outdoor. Untuk anggrek yang dikonservasi secara eks-situ bisa dilakukan di rumah kaca. Selain anggrek hidup, untuk anggrek-anggrek yang tidak dapat hidup di lokasi pariwisata, bisa dilihat dalam bentuk tiruannya ataupun yang sudah diawetkan.

Kegiatan interaksi yang dimaksudkan adalah kegiatan menanam anggrek dari benih. Tidak hanya sampai kegiatan menanam, tapi juga merawat tanaman anggrek agar dapat berbunga hingga memetik bunga. Kegiatan ini dilakukan di taman yang berbentuk outdoor dan semi outdoor. Dalam kegiatan ini diharapkan para wisatawan yang datang tidak hanya dapat pelajaran mengenai anggrek tetapi juga sadar akan pentingnya kegiatan yang tidak merusak 
habitat anggrek dan tanaman lainnya ketika kembali ke lingkungannya. Aktivitas pendukung yang disediakan berupa pameran, penelitian, kuliner, dan komersial.

Selain kegiatan yang berhubungan langsung dengan anggrek. Aktivitas yang diberikan adalah pameran, karena banyaknya pameran mengenai anggrek. Sehingga mampu melayani kebutuhan pameran tersebut dalam ukuran kecil hingga besar. Bukan hanya pada fasilitas indoor, tapi fasilitas outdoor bisa digunakan untuk kegiatan pameran.

Untuk menunjang proyek dibutuhkan kegiatan penelitian. Kegiatan penelitian ini menghasilkan jenis anggrek yang lebih baik (sehat dan cepat berbuah) dan varietas anggrek silangan. Ketika berkunjung kesuatu objek pariwisata, adanya fungsi kuliner bisa menjadi suatu titik pertemuan, tempat beristirahat, dan tempat untuk makan/minum ketika sedang/sudah mengunjungi objek pariwisata tersebut. Aktivitas yang terakhir adalah untuk komersial. Wisatawan bisa membeli suatu produk yang berkaitan dengan objek pariwisata tersebut. Pada objek wisata ini, produk yang dijual bisa berupa suvenir-suvenir seputar anggrek, maupun benih-benih bunga anggrek yang dijual.

\section{Zoning}

Pada sisi utara tapak yang berbatasan langsung dengan sungai diolah menjadi promenade. Sehingga pada bagian utara menjadi zona outdoor pada tapak. Pada bagian timur yang merupakan akses menuju Jl. Gatot Subroto dijadikan sebagai pintu masuk kendaraan. Pada sebelah timur menjadi zona semi outdoor, karena tidak membutuhkan bangunan tertutup yang berfungsi menyambut wisatawan. Hanya dibutuhkan sedikit bangunan untuk melindungi wisatawan dari hujan maupun panas matahari. Pada bagian barat yang berbatasan dengan Jl. Poncol yang merupakan penyambut dari Kawasan Senayan dan Kebayoran digunakan sebagai pintu masuk bagi pejalan kaki yang baru mengunjungi kedua kawasan tersebut. Dari zoning, didapatkan pada bagian pusat tapak merupakan zona indoor. Sehingga untuk parkir ditempatkan di zona indoor dalam rupa basement. Sehingga tidak menghalangi akar tumbuhan pada zona outdoor dan semi outdoor.

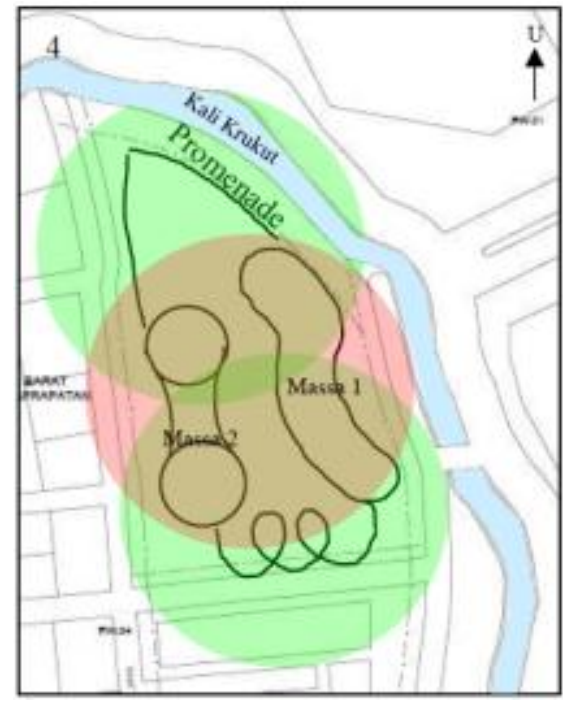

Gambar 2. Zoning dalam Tapak Sumber: Olahan penulis, 2018

Dengan adanya teknologi pemanfaatan ruangan secara vertikal, dapat dimanfaatkan untuk mengembangkan budi daya anggrek dengan beberapa penyesuaian terhadap pola hidup tanaman anggrek yang unik. Tanaman anggrek memiliki cara hidup yang bisa hidup ditanah, menumpang pada tanaman lainnya, dan menempel pada benda - benda mati (batu, tebing, bangunan).

Tanaman anggrek sendiri merupakan satu- satunya komoditas tanaman hias yang masuk ke 
dalam kategori prioritas dalam hortikultura. Hal tersebut dapat dilihat dari besarnya indikasi akan permintaan dan ketertarikan masyarakat terhadap tanaman hias ini. Selain itu, anggrek juga masuk kedalam kategori unggulan hortikultura. Beberapa jenis dari tanaman ini sudah dikembangkan untuk bisa hidup diluar habitat aslinya dan memiliki variasi yang beragam. Proyek ini direncanakan untuk memamerkan tanaman anggrek dari Indonesia. Anggrek yang dipamerkan dibagi ke dalam tiga ruang. Ruang pertama merupakan tempat memamerkan anggrek yang tinggal di iklim panas hingga sedang. Sehingga tanaman anggrek dapat dibiarkan bebas tumbuh tanpa bantuan iklim buatan.

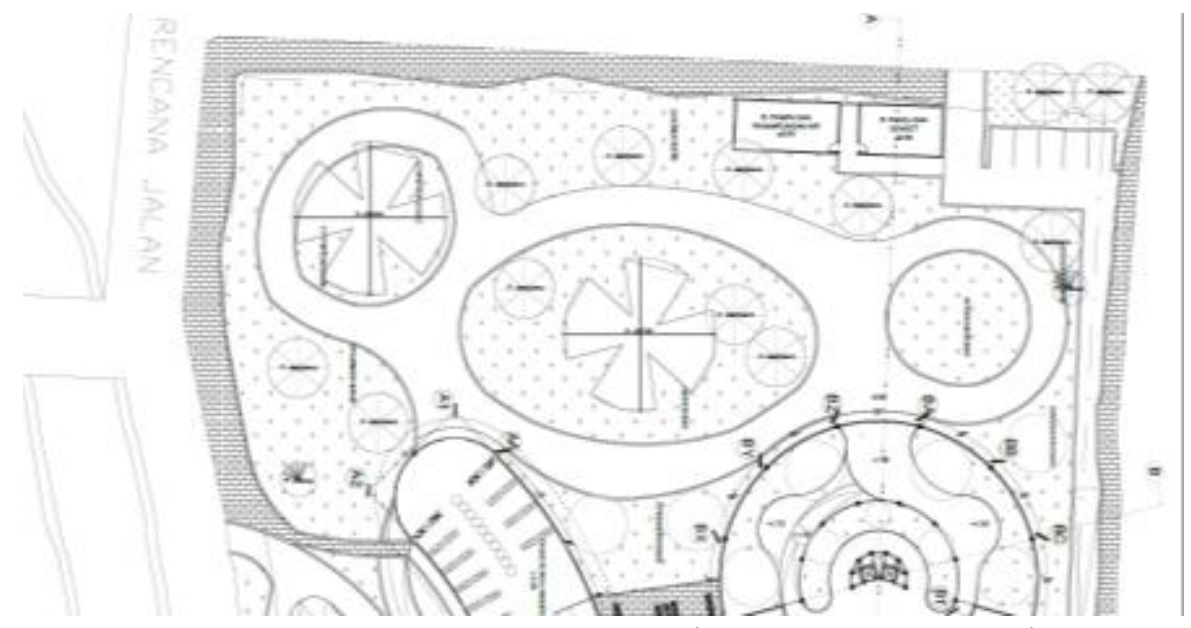

Gambar 3. Ruang Pertama (Taman Semi Outdoor)

Sumber: Olahan penulis, 2018

Ruang kedua merupakan tempat memamerkan anggrek yang tinggal di iklim dingin. Ruang kedua ini berupa rumah kaca, karena tanaman anggrek butuh iklim buatan untuk tumbuh.

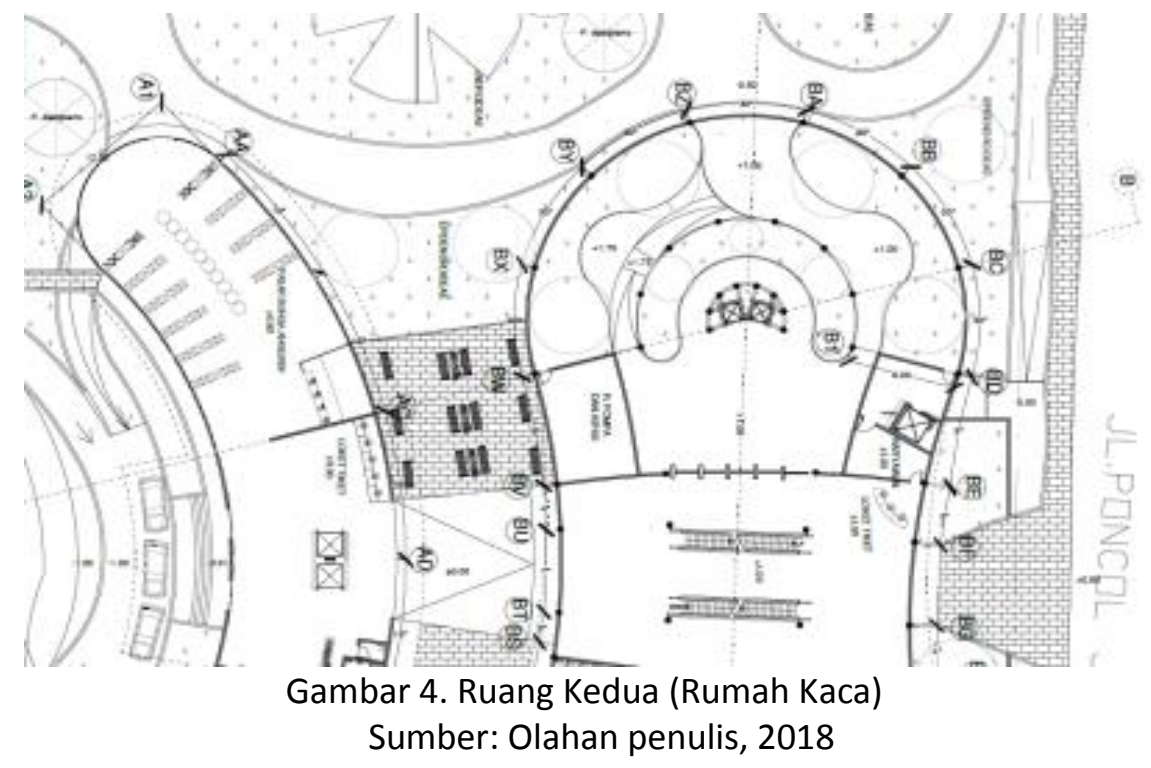

Ruang ketiga adalah ruang yang dibuat dengan tujuan utama membudidayakan anggrek. Ruang ketiga ini berupa kebun anggrek, Selain memamerkan tanaman anggrek yang hidup, proyek ini juga memamerkan jenis-jenis anggrek Indonesia dalam rupa miniatur dan juga secara digital, yang dibagi-bagi berdasarkan kawasan tempat tinggalnya. 


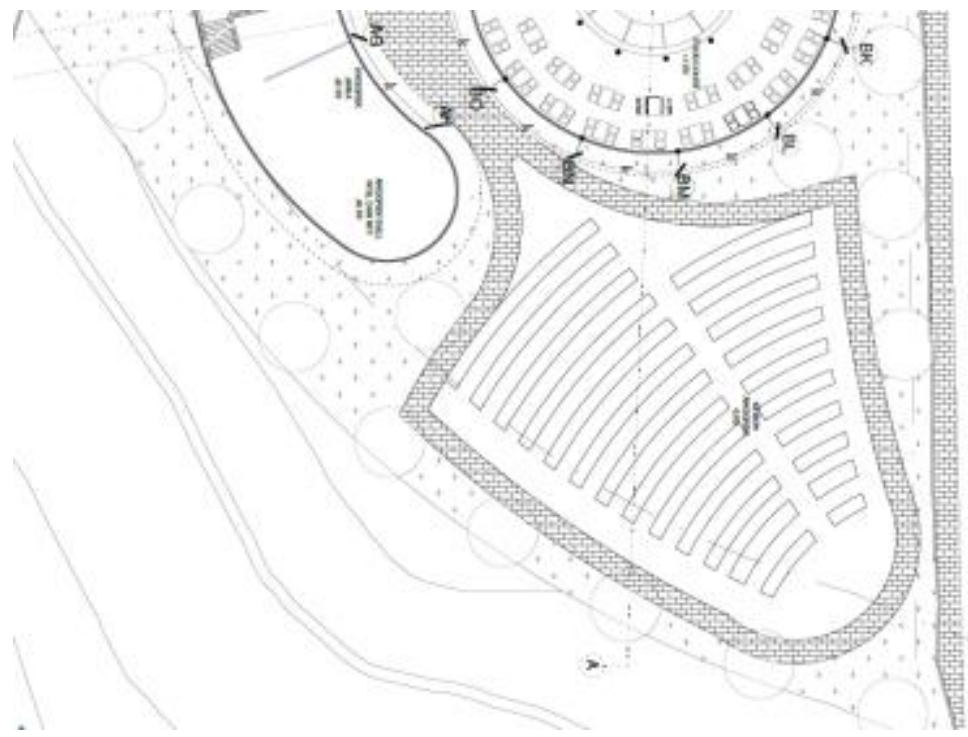

Gambar 5. Ruang Ketiga (Kebun Anggrek)

Sumber: Olahan penulis, 2018

Selain ketiga ruang di atas yang menawarkan aktivitas observasi dan interaksi, proyek ini juga menawarkan kelas merangkai bunga dan kelas menanam anggrek. Kedua jenis kelas tersebut diadakan pada hari-hari tertentu, sehingga wisatawan yang ingin mengikuti kelas dapat menyesuaikan dengan jadwal yang tersedia. Hal tersebut dikarenakan tenaga pengajar didatangkan dari luar proyek. Pada lantai 1 dan 2 terdapat food court. Menawarkan beragam jenis makanan karena terdiri dari beberapa penjual. Wisatawan yang datang hanya untuk makan, food court ini dapat diakses secara bebas.

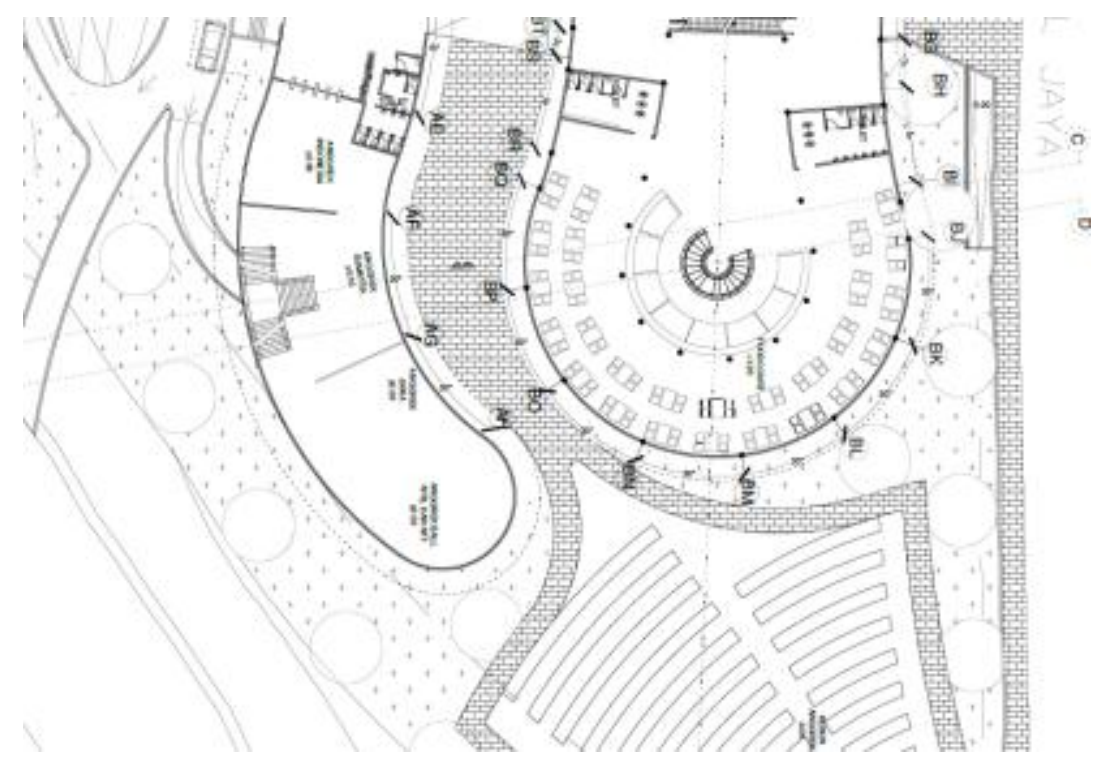

Gambar 6. Foodcourt di Lantai 1

Sumber: Olahan penulis, 2018

Pada puncak rumah kaca terdapat cafe yang menawarkan jenis makanan ringan dan minuman, dengan memiliki pemandangan rumah kaca dan taman semi-outdoor dan outdoor. Disediakan pula fasilitas pasar bunga anggrek untuk penunjung yang hanya bermaksud datang untuk membeli bunga. Di pasar, pembeli bisa membeli bunga anggrek dan berbagai macam kebutuhan lainnya untuk menanam. 


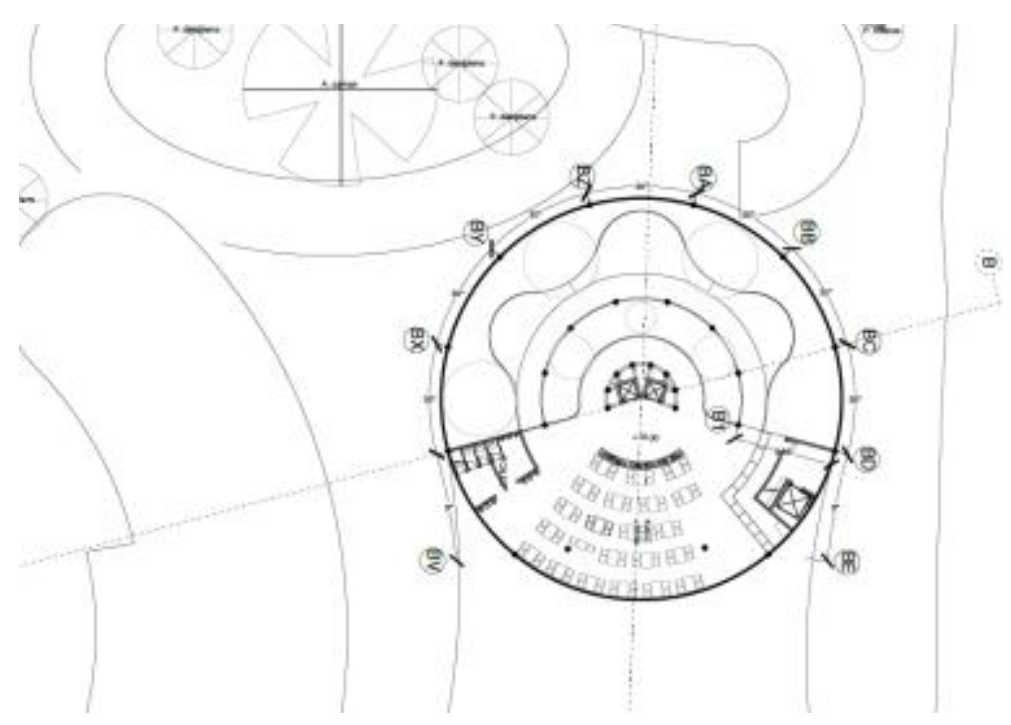

Gambar 7. Cafe di Lantai 4

Sumber: Olahan penulis, 2018

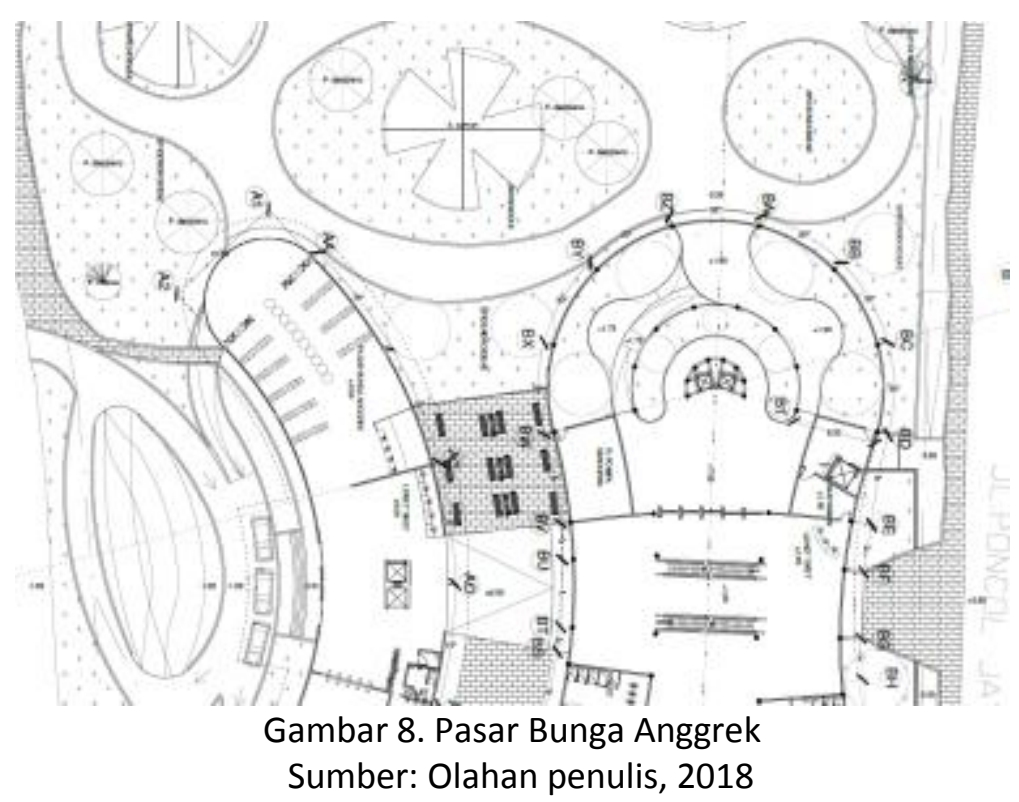

Apabila ditinjau dari proporsi program ruang maka zona aktivitas penerimaan memiliki luas sebesar 6,3\% dari luas keseluruhan bangunan. Aktivitas interaksi dan observasi, memiliki luas 69,89\% dari luas keseluruhan bangunan untuk bagian indoor dan 42,1\% dari luas keseluruhan tapak untuk bagian outdoor. Aktivitas komersial, pengelola, dan penelitian masing - masing memiliki luas 18,75\%, 3,25\%, dan 1,88\% dari luas keseluruhan bangunan (Tabel 1).

Pada proyek ini wisatawan dapat masuk dari dua pintu yaitu, pintu barat dan pintu timur. Pintu barat diperuntukan untuk wisatawan yang datang dengan berjalan kaki. Karena pada bagian barat, hierarki jalan lebih rendah dibanding dengan sebelah timur, selain itu zonasi di bagian barat berupa zonasi perkantoran, perdagangan dan jasa dengan Koefisien Lantai Bangunan (KLB) yang lebih rendah. Sedangkan untuk pintu timur diperuntukan untuk wisatan yang datang dengan menggunakan kendaraan bermotor maupun berjalan kaki. Karena hierarki yang lebih tinggi. 
Kedua pintu masuk bisa diakses dari pintu masuk lainnya. Setelah melewati pintu masuk wisatawan bisa membeli tiket dengan pilihan keempat ruang utama observasi anggrek. Wisatawan kemudian dibebaskan menentukan tempat-tempat yang ingin dikunjunginya. Untuk wisatawan yang datang hanya untuk berbelanja, makan, dan mengikuti kelas interaksi pada proyek ini, tidak perlu membeli tiket.

Massa proyek ini dibagi menjadi 2 massa utama. Massa pertama berada persis di sebelah Kali Krukut. Massa yang pertama mengikuti bentuk sungai, namun diberi cekungan pada bagian pintu masuk kendaraan. Massa kedua berada di sebelah JI. Poncol Jaya. Massa kedua ini melanjutkan bentuk dari massa sebelumnya. Pada massa kedua di bagian selatannya mempunyai tinggi maksimal untuk memenuhi Peraturan Zonasi yang berfungsi sebagai rumah kaca.

Pada sebelah utara, tidak ada massa bangunan sama sekali dengan tujuan menyediakan kebun anggrek dan promenade. Pada sebelah selatan, terdapat massa berupa penutup atap. Sehingga zona selatan selalu bisa digunakan. Wisatawan pada zona selatan terlindungi dari hujan dan panas matahari.

Tabel 1. Program Ruang

\begin{tabular}{|c|c|c|}
\hline Aktivitas & Nama Ruang & Luas $\left(\mathrm{m}^{2}\right)$ \\
\hline \multicolumn{3}{|l|}{ LANTAI 1} \\
\hline Penerimaan & Informasi, Loker, Hall & 550 \\
\hline Interaksi dan Observasi & $\begin{array}{l}\text { Herbarium, Taman Rumah Kaca, Gudang, } \\
\text { Toilet }\end{array}$ & 3010 \\
\hline Komersial & Pasar Bunga, Food court, Toilet & 1087 \\
\hline Servis & Toilet, Janitor & 240 \\
\hline \multicolumn{3}{|l|}{ LANTAI 2} \\
\hline Interaksi dan Observasi & $\begin{array}{l}\text { Hall, Herbarium, Rumah Kaca, Workshop, } \\
\text { Gudang, Toilet }\end{array}$ & 1686,2 \\
\hline Komersial & Foodcourt & 700 \\
\hline Pengelola & $\begin{array}{l}\text { R. Tunggu, R. Rapat, R. Manager, R. Divisi } \\
\text { (Administrasi, Keuangan, Personalia) Pantry }\end{array}$ & 283 \\
\hline Servis & Toilet, Janitor & 34 \\
\hline \multicolumn{3}{|l|}{ LANTAI 3} \\
\hline Interaksi dan Observasi & Rumah Kaca & 700 \\
\hline Penelitian & $\begin{array}{l}\text { Laboratorium (Nutrisi Tanaman, Botani, } \\
\text { Patologi, Propagasi Tanaman), R. Ganti, Toilet }\end{array}$ & 164 \\
\hline Servis & Toilet, Janitor & 34 \\
\hline \multicolumn{3}{|l|}{ LANTAI 4} \\
\hline Interaksi dan Observasi & Rumah Kaca & 700 \\
\hline Komersial & Kafe & 164 \\
\hline Servis & Toilet, Janitor & 34 \\
\hline Sirkulasi 30\% & & 2616,7 \\
\hline Total & & 11338,8 \\
\hline
\end{tabular}

Sumber: Olahan penulis, 2018 


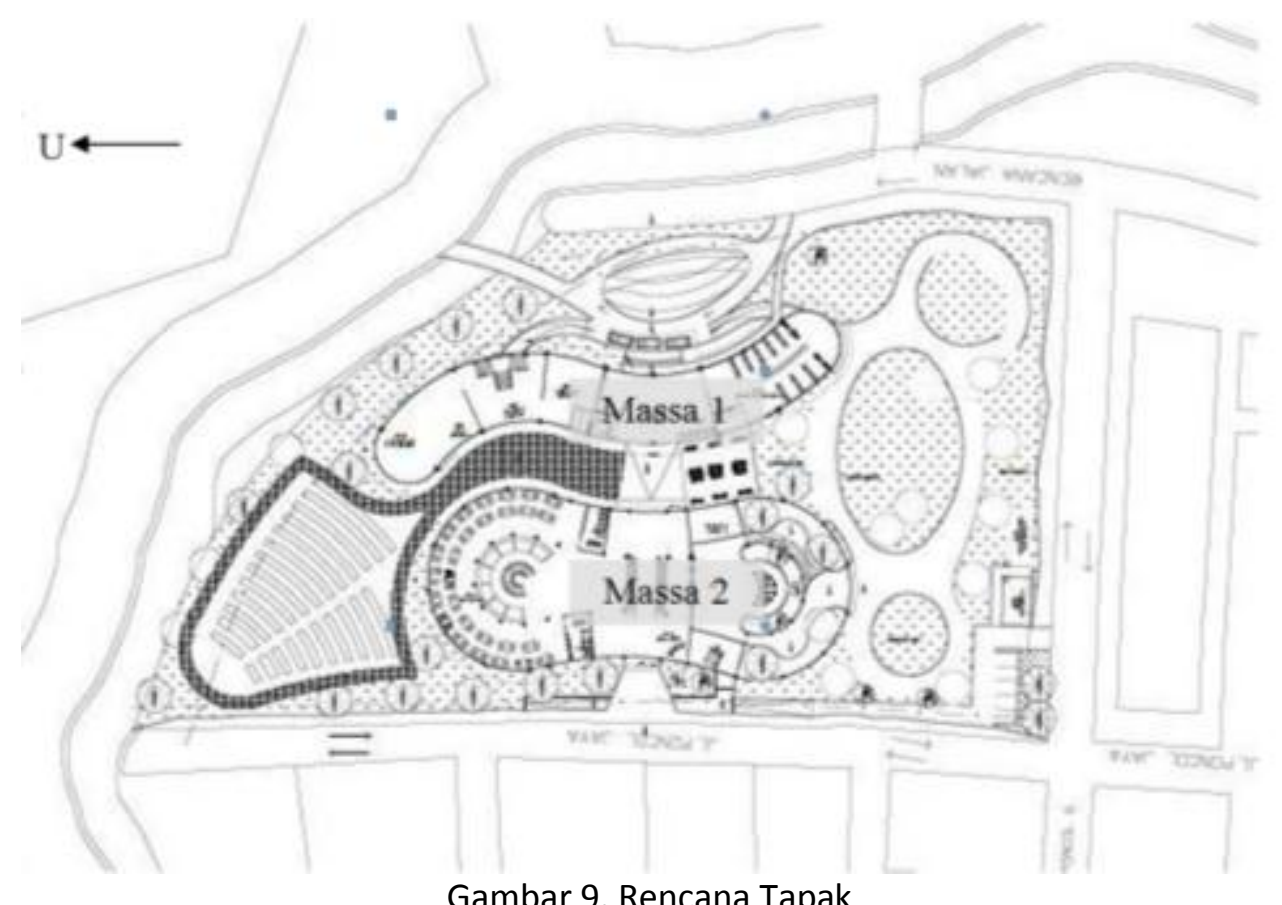

Gambar 9. Rencana Tapak

Sumber: Olahan penulis, 2018

Massa yang pertama mengikuti bentuk sungai, namun diberi cekungan pada bagian pintu masuk kendaraan. Dari tampak timur terlihat penyelesaian bangunan pada bagian sebelah kanan tertutup. Sesuai dengan ruang yang ada didalamnya, yaitu herbarium, yang tidak cocok terkena sinar matahari. Pada tampak timur, penyelesaian bagian sebelah kiri dibuat transparan, ruang didalamnya adalah kantor pengelola dan pasar bunga.

Massa kedua berada di sebelah Jl. Poncol Jaya. Massa kedua ini melanjutkan bentuk dari massa sebelumnya. Pada massa kedua di bagian selatannya mempunyai tinggi maksimal untuk memenuhi Peraturan Zonasi, berfungsi sebagai rumah kaca. Dari tampak barat, terlihat penyelesaian bagian sebelah kanan adalah transparan (fungsi didalamnya rumah kaca) dan penyelesaian bagian sebelah kiri adalah terbuka disebelah (fungsi didalamnya food court). Sehingga pada tampak barat, penyelesaian bagian tengah merupakan transisi dari bagian kanan menuju kiri. Pada sebelah utara, tidak ada massa sama sekali, berfungsi sebagai kebun anggrek dan promenade.

Pada tampak utara terlihat massa 1 di kiri dan massa 2 di kanan. Pada massa 1 dibuat tertutup, ruang didalamnya adalah herbarium. Pada massa 2 dibuat terbuka, ruang didalamnya adalah food court, sehingga wisatawan bisa menikmati kuliner sambil melihat kearah kebun anggrek dan promenade.

Pada sebelah selatan, terdapat massa berupa penutup atap. Sehingga zona taman selatan selalu bisa digunakan. Wisatawan pada zona selatan terlindungi dari hujan dan panas matahari. Zona taman selatan menjadi penghubung antara massa 1.

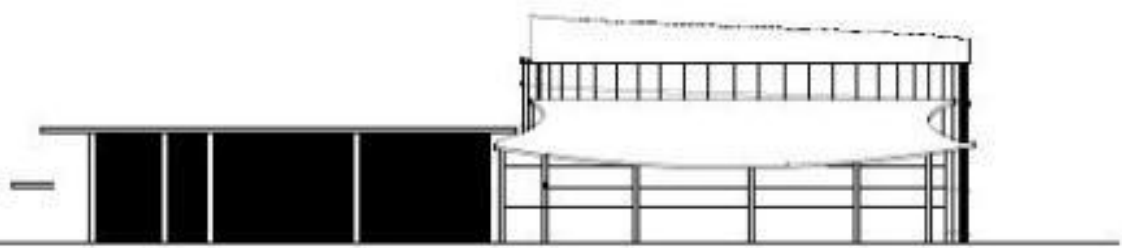

Gambar 9. Tampak Utara

Sumber: Olahan penulis, 2018 


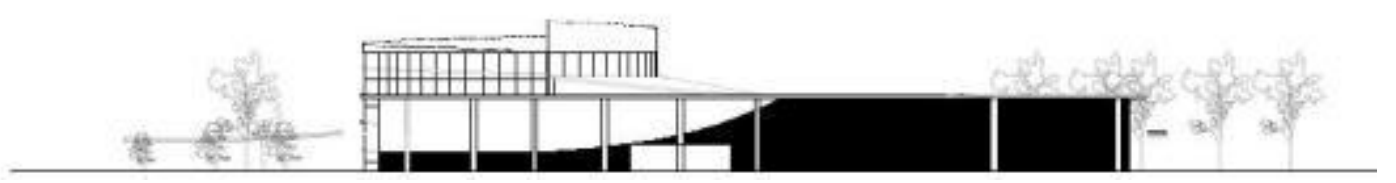

Gambar 10. Tampak Timur

Sumber: Olahan penulis, 2018

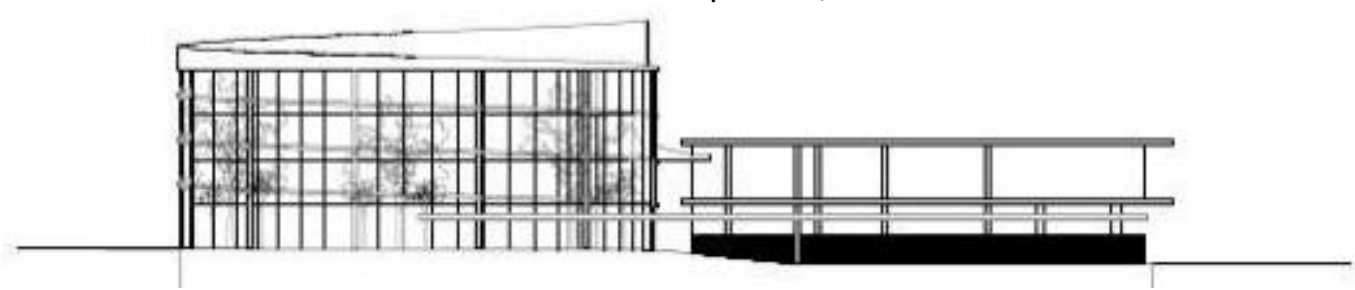

Gambar 11. Tampak Selatan

Sumber: Olahan penulis, 2018

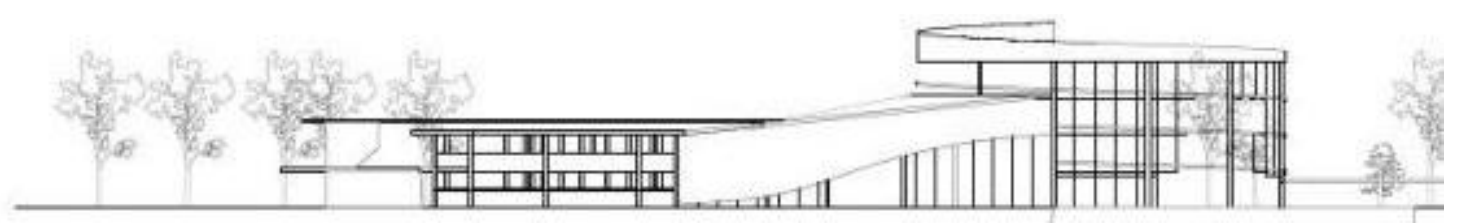

Gambar 12. Tampak Barat

Sumber: Olahan penulis, 2018

\section{KESIMPULAN DAN SARAN}

Penggunaan metode desain pragmatis sesuai dengan prinsip - prinsip Pengembangan Wisata Ekologi yang menjunjung tinggi sifat ramah lingkungan. Sehingga proyek ini menghasilkan banyaknya ruang outdoor dan semi outdoor. Tidak hanya ramah lingkungan, tapi juga ramah dengan atraksi utama berupa flora anggrek.

Dengan banyaknya ruang outdoor dan semi outdoor ini memberikan pengalaman alam yang baik bagi para wisatawan. Pengalaman yang baik saat berada di ruang alam diharapkan menumbuhkan rasa cinta terhadap flora anggrek dan juga habitatnya. Tidak hanya pada flora anggrek namun wisatawan juga dapat sadar betapa pentingnya ruang hijau bagi manusia, flora, dan fauna.

\section{UCAPAN TERIMA KASIH}

Penulis mengucapkan terima kasih kepada Tuhan Yang Maha Esa karena-Nya sehingga artikel Jurnal Stupa ini dapat terselesaikan. Penulis juga mengucapkan terima kasih kepada pihak Kelurahan Kuningan Barat yang telah membantu dalam proses survey lokasi dan pemberian data.

\section{REFERENSI}

Assagaf, M. H. (2012). 1001 Spesies Anggrek Yang Tumbuh dan Berbunga di Indonesia. Indonesia: Kataelha.

Broadent, G. (1973). The Design In Architecture. Amerika Serikat.

Purwanto, A. W. (2016). Anggrek : Budi Daya dan Perbanyakan. Yogyakarta: LPPM UPN Veteran Yogyakarta.

Specht, J. (2014). Architectural Tourism: Building for Urban Travel Destination. Jerman: Springer Gabler.

Suwantoro, G. (2004). Dasar - dasar Pariwisata. Yogyakarta: Andi Yogyakarta.

Y, S., \& B, S. (2003). Merawat Anggrek. Jakarta: Penebar Swadaya.

Ziffer, K. A. (1989). Ecotourism: The Uneasy Alliance. Washington DC: Conservation International. 